\title{
Progressive multifocal leukoencephalopathy and granule cell neuronopathy with novel mutation flanking VP1 C-terminus in natalizumab- extended interval dosing
} Torge Rempe, MD, Qin Wang, PhD, Qi Wu, PhD, Varalakshmi Ballur Narayana Reddy, MD,
Zachary Newcomer, DO, Augusto Miravalle, MD, and Yang Mao-Draayer, MD, PhD

Neurol Neuroimmunol Neuroinflamm 2020;7:e709. doi:10.1212/NXI.0000000000000709

\author{
Correspondence \\ Dr. Rempe \\ torge.rempe@neurology.ufl.edu \\ or Dr. Mao-Draayer \\ maodraay@umich.edu
}

Reactivation of a dormant infection with the John Cunningham virus (JCV) can lead to the rare neurologic disorders progressive multifocal leukoencephalopathy (PML) and granule cell neuronopathy $(\mathrm{GCN})$, a cerebellar syndrome with progressing cerebellar atrophy. ${ }^{1}$ Here, we present a case of infratentorial PML with concomitant GCN in extended interval dosing (EID) of natalizumab associated with a novel mutation at 7 th position after the $\mathrm{C}$-terminus of viral capsid protein VP1 in addition to the common noncoding regulatory region (NCRR) mutation.

\section{Case report}

In March 2018, a 65-year-old woman presented with progressive symptoms of holocephalic headache, dizziness, nausea, and psychomotor slowing as well as balance difficulties and left hemibody weakness that started 2 weeks before admission. Her medical history was significant for relapsing-remitting MS initially diagnosed in 2000 with mild residual right-sided weakness. Because of the side effects of previous disease modifying therapy with interferons (flu-like symptoms) and glatiramer acetate (injection site reactions), natalizumab treatment was initiated in August 2010 and discontinued in March 2014 in light of her initial positive anti-JCV serostatus. Owing to the gastrointestinal side effects of subsequent therapy with teriflunomide and dimethyl fumarate (short treatment duration without associated lymphopenia), natalizumab therapy was reinitiated in August 2015 and infusion frequency was changed to EID (initially every 8 weeks, then every 6 weeks) for $>2$ years before the symptom onset.

On admission, mild tetraparesis (4/5) more evident on the left, diffuse 3+ hyperreflexia, positive bilateral Babinski reflexes, and impaired balance with inability to walk were present. Initially observed left-sided hemiataxia evolved into bilateral dysmetria pronounced on the left. MRI of the brain showed abnormal T2/fluid-attenuated inversion recovery hyperintensities in bilateral cerebellar hemispheres with extension into the left middle cerebellar peduncle and the cerebellar atrophy (figure).

The patient's most recent anti-JCV antibody indices (Quest Diagnostics, San Juan Capistrano, CA) were 3.32 (July 2016) and 3.42 (October 2017). Her absolute lymphocyte count ranged between $2.18-5.24 \times 10^{3} / \mu \mathrm{L}$. JCV multiplex quantitative PCR analysis performed by the NIH was positive for 1,156 copies $/ \mathrm{mL}$ in the CSF and 1,070 copies $/ \mathrm{mL}$ in plasma of the NCRR variant most commonly associated with PML. ${ }^{2}$ VP1 mutational analysis of the patient's plasma and CSF (supplementary material 1, links.lww.com/NXG/A250) did not show previously published common mutations at positions L55, K60, S61, D66, S267/S269, or Q271 nor in the C-terminus. However, a novel mutation at 7th position after VP1 C-terminus was detected in the patient's 


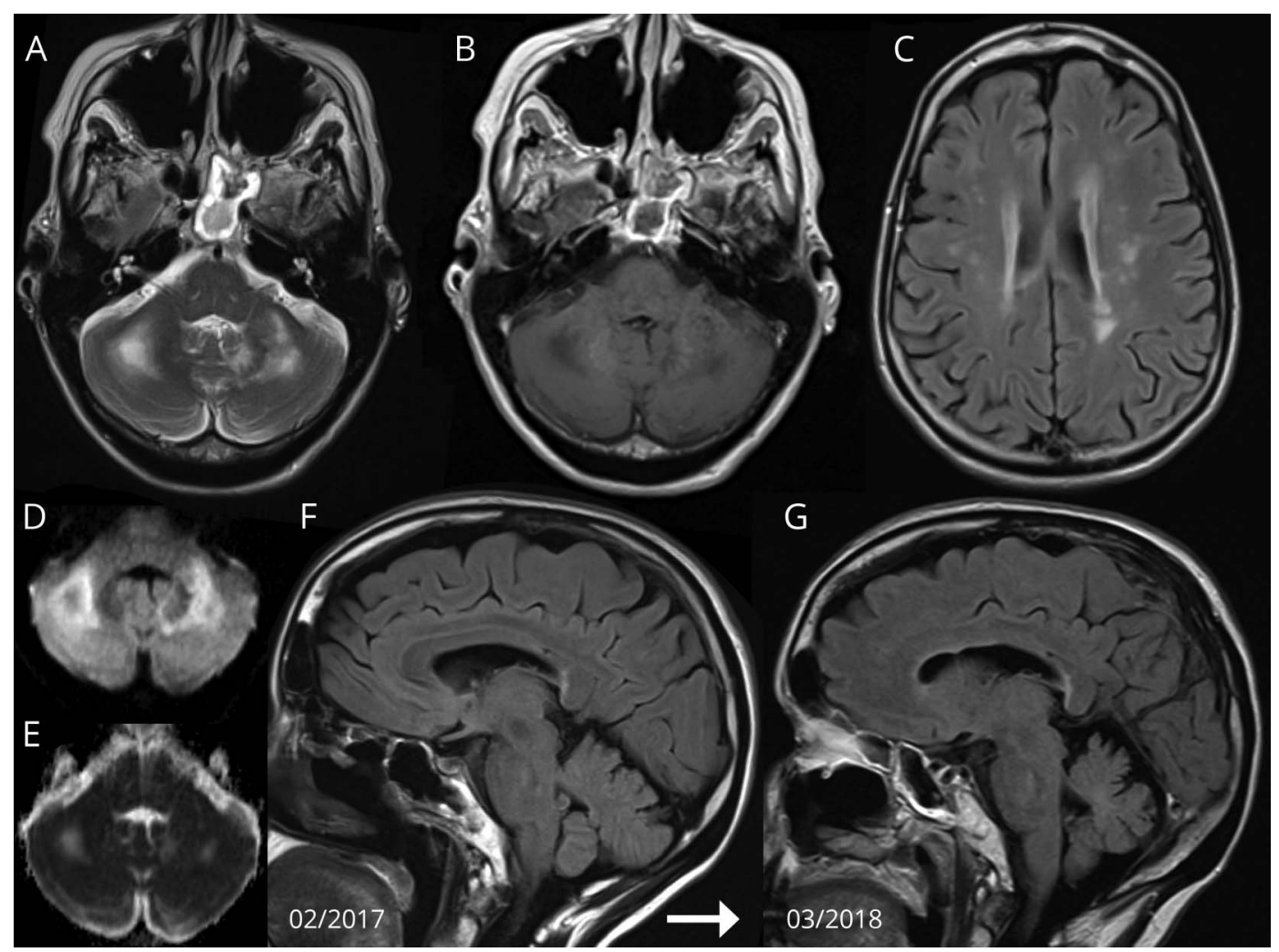

(A) Axial T2-weighted section showing hyperintensity in the white matter of the bilateral cerebellar hemispheres with extension into the middle cerebellar peduncle on the left (incidental mucosal thickening and an air-fluid level are present in the left sphenoid sinus); (B) axial gadolinium-enhanced T1-weighted section without evident contrast enhancement of the lesion; (C) axial FLAIR-weighted section with multiple periventricular foci of hyperintensity consistent with the patient's previous MS lesions; (D, E) diffusion-weighted imaging (D) and apparent diffusion coefficient (E) with central area of T2 shine-through and rim of diffusion restriction; and $(F, G)$ sagittal FLAIR-weighted sections 13 months before presentation (February 2017; F) and at the time of presentation (March 2018 = most recent image; G) depicting interval development of cerebellar atrophy. FLAIR = fluid-attenuated inversion recovery.

plasma and CSF (nucleotide triplet ATA isoleucine/I [hydrophobic amino acid] to AAA lysine/K [hydrophilic amino acid]).

The patient received a 3-day course of apheresis for natalizumab removal. She was subsequently started on a 5-day course of $1,000 \mathrm{mg}$ IV-methylprednisolone, maraviroc $150 \mathrm{mg}$ twice daily, and nightly mirtazapine $15 \mathrm{mg}$. After discharge to acute rehab, the patient developed a severe aspiration pneumonia nonresponsive to antibiotics. She was transitioned to hospice care, and she passed away from aspiration pneumonia/sepsis approximately 2 months after discharge. An autopsy was not performed.

\section{Discussion}

Although EID has been shown to significantly lower the risk of PML, ${ }^{3}$ the reported case emphasizes that natalizumabassociated PML can also occur in EID. Furthermore, the case demonstrates concurrent cerebellar atrophy and infratentorial white matter changes associated with coexistence of the common NCRR variant and a novel mutation in the noncoding region after the VP1 C-terminus.
VP1 BC (amino acids 57-90) and HI (amino acids 268-278) loop mutations occur frequently ( $81 \%-93 \%)$ in JCV isolates of patients with PML. ${ }^{4}$ Deletions, duplications, and mutations in the VP1 C-terminus named $\mathrm{JCV}_{\mathrm{GCN} 1-8}$ have been associated with JCV-GCN. ${ }^{5}$ Although we did not identify the previously described VP1 mutations, we detected a novel mutation at 7 th position after the VP1 C-terminus that we termed $\mathrm{JCV}_{\mathrm{GCN} 9}$.

Concomitant cerebellar/pontine white matter changes have been observed in GCN, and it has been postulated that this could be because of a coinfection with 2 different JCV strains. ${ }^{6}$ While the NCRR variant is responsible for the PML-typical white matter changes, a different JCV strain with a VP1 C-terminus mutation leads to JCV-GCN with its characteristic cerebellar atrophy. ${ }^{7}$ The current case demonstrates an association between the concurrence of PML-lesions and JCV-GCN and the coinfection with the virulent NCRR variant and a novel mutation in the noncoding region flanking the VP1 C-terminus. The discovered mutation differs from the previous GCN mutations because it is located in the noncoding region after the VP1 C-terminus, and its potential pathogenicity will need to be further evaluated. A limiting factor is also the possibility that additional JCV strains with previously reported GCN mutations 
might not have been captured without the sequencing of multiple clones if they only represent a minority strain. ${ }^{5}$ Future research is needed to further characterize the relationship between various JCV mutations in GCN and PML.

\section{Study funding}

No targeted funding.

\section{Disclosure}

T. Rempe, Q. Wang, Q. Wu, V. Ballur Narayana Reddy and Z. Newcomer report no disclosures. A. Miravalle has received consulting and/or speaker fees from Celgene, Alexion, Novartis, Genentech, Genzyme, Biogen, EMD Serono; and research support from Novartis, Serono, Genzyme. Y. MaoDraayer has received consulting and/or speaker fees from Acroda, Biogen, Bayer Pharmaceutical, Celgene, Teva, Genentech, Novartis, Sanofi-Genzyme, and EMD Serono; and research support from NIH NINDS R01-NS080821, NIAID Autoimmune Center of Excellence UM1-AI110557, SanofiGenzyme, Novartis, and Chugai. Go to Neurology.org/NN for full disclosures.

\section{Publication history}

Received by Neurology: Neuroimmunology \& Neuroinflammation August 5, 2019. Accepted in final form January 29, 2020.

\section{Appendix Authors}

\begin{tabular}{lll}
\hline Name & Location & Contribution \\
\hline Torge Rempe, MD & University of Florida & Draft of the manuscript \\
\hline Qin Wang, PhD & $\begin{array}{l}\text { University of } \\
\text { Michigan }\end{array}$ & $\begin{array}{l}\text { Mutational analysis, } \\
\text { revision and critique of the } \\
\text { manuscript }\end{array}$ \\
\hline
\end{tabular}

Appendix (continued)

\begin{tabular}{lll}
\hline Name & Location & Contribution \\
\hline Qi Wu, PhD & $\begin{array}{l}\text { University of } \\
\text { Michigan }\end{array}$ & $\begin{array}{l}\text { Revision and critique of the } \\
\text { manuscript }\end{array}$ \\
\hline $\begin{array}{l}\text { Varalakshmi } \\
\text { Ballur Narayana } \\
\text { Reddy, MD }\end{array}$ & University of Florida & $\begin{array}{l}\text { Treatment of patient, } \\
\text { revision and critique of the } \\
\text { manuscript }\end{array}$ \\
\hline $\begin{array}{l}\text { Zachary } \\
\text { Newcomer, Do }\end{array}$ & University of Florida & $\begin{array}{l}\text { Treatment of patient, } \\
\text { revision and critique of the } \\
\text { manuscript }\end{array}$ \\
\hline $\begin{array}{l}\text { Augusto } \\
\text { Miravalle, MD }\end{array}$ & $\begin{array}{l}\text { University of } \\
\text { Florida; University } \\
\text { of Colorado }\end{array}$ & $\begin{array}{l}\text { Treatment of patient, } \\
\text { revision and critique of the } \\
\text { manuscript }\end{array}$ \\
\hline $\begin{array}{l}\text { Yang Mao- } \\
\text { Draayer, MD, PhD }\end{array}$ & $\begin{array}{l}\text { University of } \\
\text { Michigan }\end{array}$ & $\begin{array}{l}\text { Mutational analysis, } \\
\text { revision and critique of the } \\
\text { manuscript }\end{array}$ \\
& $\begin{array}{l}\text { mand } \\
\text { Mand }\end{array}$ &
\end{tabular}

\section{References}

1. Bartsch $\mathrm{T}$, Rempe $\mathrm{T}$, Leypoldt $\mathrm{F}$, et al. The spectrum of progressive multifocal leukoencephalopathy: a practical approach. Eur J Neurol 2019;26:566-e41.

2. Ryschkewitsch CF, Jensen PN, Major EO. Multiplex qPCR assay for ultra sensitive detection of JCV DNA with simultaneous identification of genotypes that discriminates non-virulent from virulent variants. J Clin Virol 2013;57: 243-248.

3. Ryerson LZ, Foley J, Chang I, et al. Risk of natalizumab-associated PML in patients with MS is reduced with extended interval dosing. Neurology 2019;93: e1452-e1462.

4. Reid CE, Li H, Sur G, et al. Sequencing and analysis of JC virus DNA from natalizumab-treated PML patients. J Infect Dis 2011;204:237-244.

5. Agnihotri SP, Dang X, Carter JL, et al. JCV GCN in a natalizumab-treated MS patient is associated with mutations of the VP1 capsid gene. Neurology 2014;83: 727-732.

6. Mills EA, Mao-Draayer Y. Understanding progressive multifocal leukoencephalopathy risk in multiple sclerosis patients treated with immunomodulatory therapies: a bird's eye view. Front Immunol 2018;9:138.

7. Wijburg MT, van Oosten BW, Murk JL, Karimi O, Killestein J, Wattjes MP. Heterogeneous imaging characteristics of JC virus granule cell neuronopathy (GCN): a case series and review of the literature. J Neurol 2015;262:65-73. 


\section{Neurology \\ Neuroimmunology \& Neuroinflammation}

Progressive multifocal leukoencephalopathy and granule cell neuronopathy with novel mutation flanking VP1 C-terminus in natalizumab-extended interval dosing

Torge Rempe, Qin Wang, Qi Wu, et al.

Neurol Neuroimmunol Neuroinflamm 2020;7;

DOI 10.1212/NXI.0000000000000709

This information is current as of March 20, 2020

Neurol Neuroimmunol Neuroinflamm is an official journal of the American Academy of Neurology.

Published since April 2014, it is an open-access, online-only, continuous publication journal. Copyright

Copyright (C) 2020 The Author(s). Published by Wolters Kluwer Health, Inc. on behalf of the American

Academy of Neurology.. All rights reserved. Online ISSN: 2332-7812.

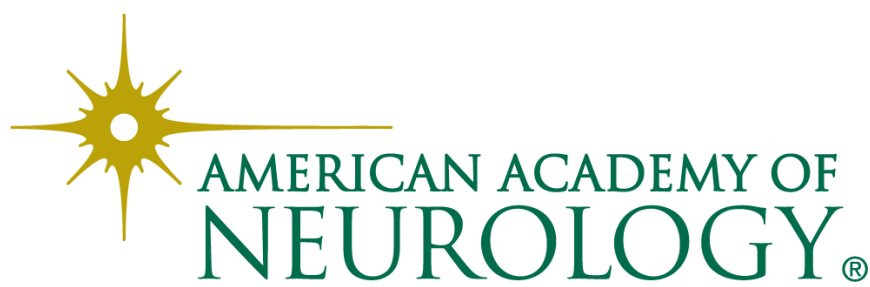




\section{Updated Information \& Services}

References

Subspecialty Collections

Permissions \& Licensing

\section{Reprints}

including high resolution figures, can be found at:

http://nn.neurology.org/content/7/3/e709.full.html

This article cites 7 articles, 0 of which you can access for free at: http://nn.neurology.org/content/7/3/e709.full.html\#\#ref-list-1

This article, along with others on similar topics, appears in the following collection(s):

All Clinical Neurology

http://nn.neurology.org//cgi/collection/all_clinical_neurology

All Immunology

http://nn.neurology.org//cgi/collection/all_immunology

All Infections

http://nn.neurology.org//cgi/collection/all_infections

Autoimmune diseases

http://nn.neurology.org//cgi/collection/autoimmune_diseases

Viral infections

http://nn.neurology.org//cgi/collection/viral_infections

Information about reproducing this article in parts (figures,tables) or in its entirety can be found online at:

http://nn.neurology.org/misc/about.xhtml\#permissions

Information about ordering reprints can be found online:

http://nn.neurology.org/misc/addir.xhtml\#reprintsus

Neurol Neuroimmunol Neuroinflamm is an official journal of the American Academy of Neurology.

Published since April 2014, it is an open-access, online-only, continuous publication journal. Copyright

Copyright $\odot 2020$ The Author(s). Published by Wolters Kluwer Health, Inc. on behalf of the American

Academy of Neurology.. All rights reserved. Online ISSN: 2332-7812.

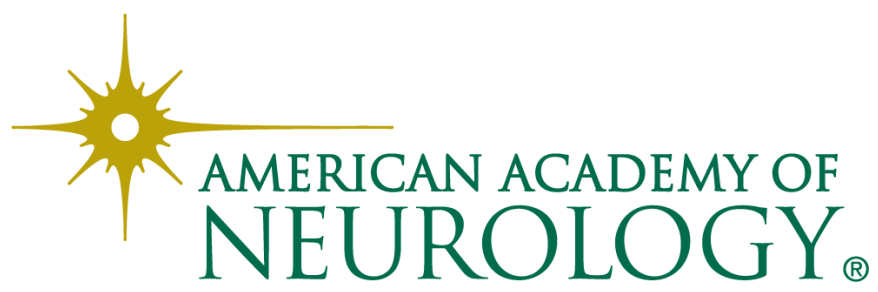

